\title{
Comparative study on pretreatment processes for different utilization purposes of
} switchgrass

Wang, Fan; Shi, Dongxiang; Han, Ju; Zhang, Ge; Jiang, Xinglin; Yang, Mingjun; Wu, Zhenying; Fu, Chunxiang; Li, Zhihao; Xian, Mo

Total number of authors:

11

Published in:

ACS Omega

Link to article, DOI:

10.1021/acsomega.0c01047

Publication date:

2020

Document Version

Publisher's PDF, also known as Version of record

Link back to DTU Orbit

Citation (APA):

Wang, F., Shi, D., Han, J., Zhang, G., Jiang, X., Yang, M., Wu, Z., Fu, C., Li, Z., Xian, M., \& Zhang, H. (2020). Comparative study on pretreatment processes for different utilization purposes of switchgrass. ACS Omega, 5(35), 21999-22007. https://doi.org/10.1021/acsomega.0c01047

\section{General rights}

Copyright and moral rights for the publications made accessible in the public portal are retained by the authors and/or other copyright owners and it is a condition of accessing publications that users recognise and abide by the legal requirements associated with these rights.

- Users may download and print one copy of any publication from the public portal for the purpose of private study or research.

- You may not further distribute the material or use it for any profit-making activity or commercial gain

- You may freely distribute the URL identifying the publication in the public portal 


\title{
Comparative Study on Pretreatment Processes for Different Utilization Purposes of Switchgrass
}

\author{
Fan Wang, Dongxiang Shi, Ju Han, Ge Zhang, Xinglin Jiang, Mingjun Yang, Zhenying Wu, \\ Chunxiang Fu, Zhihao Li, Mo Xian, and Haibo Zhang*
}

Cite This: ACS Omega 2020, 5, 21999-22007

Read Online

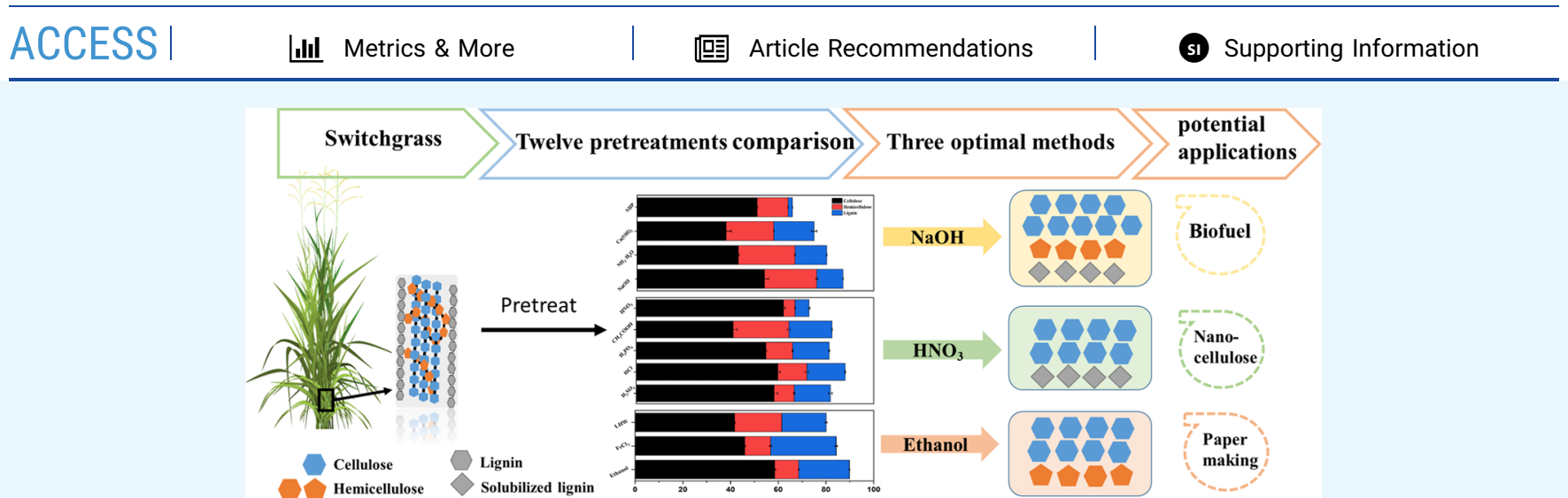

ABSTRACT: Switchgrass (Panicum virgatum, L., Poaceae) with the advantages of high cellulose yield, and high growth even under low input and poor soil quality, has been identified as a promising candidate for production of low-cost biofuels, papermaking, and nanocellulose. In this study, 12 chemical pretreatments on a laboratory scale were compared for different utilization purposes of switchgrass. It was found that the pretreated switchgrass with sodium hydroxide showed considerable potential for providing mixed sugars for fermentation with $11.10 \%$ of residual lignin, $53.85 \%$ of residual cellulose, and $22.06 \%$ of residual hemicellulose. The pretreatment with $2.00 \%(\mathrm{v} / \mathrm{v})$ nitric acid was the best method to remove $78.37 \%$ of hemicellulose and $39.82 \%$ of lignin under a low temperature $\left(125^{\circ} \mathrm{C}, 30 \mathrm{~min}\right)$, which can be used in the production of nanocellulose. Besides, a completely randomized design analysis of switchgrass pretreatments provided the alternative ethanol organosolv delignification of switchgrass for the papermaking industry with a high residual cellulose of $58.56 \%$. Finally, scanning electron microscopy (SEM), X-ray diffraction (XRD), and Fourier-transform infrared spectroscopy (FT-IR) were carried out to confirm the changes in functional groups, crystallinity, and thermal behavior of the three materials, respectively, from the optimal pretreatments.

\section{INTRODUCTION}

Lignocellulosic biomass provides more than just mixed sugars for fermenting to biofuels and other biomaterials, which also plays an essential role in the pulp and paper industry as well as nanocellulose production. ${ }^{1}$ These conversions are multistep processes involving pretreatment, which is critical to deconstruct the main recalcitrance of lignocellulosic plant cell walls due to the hemicellulose and lignin. ${ }^{2}$ Moreover, the pretreatment has proved to lower the overall cost of lignocellulose conversion and to improve the process towards making the concept of biorefinery a reality. ${ }^{3,4}$ In the last two decades, several pretreatments including physical, chemical, biological, and combinatorial methods have been developed to improve the conversion process of renewable biomass feedstocks. ${ }^{5,6}$ The efficiency of the pretreatment step depends on several factors such as feedstock properties, reactor design, and reaction conditions. Usually, pretreatments conducted at relatively low temperatures and in a short time can be used to recover the cellulose, hemicellulose, and lignin of the biomass for further conversion and valorization. ${ }^{7}$ Different lignocellulosic biomass feedstocks require different pretreatment methods for overcoming the natural recalcitrance. An ideal pretreatment process should release more cellulose and make lignocellulose susceptible to the subsequent steps. ${ }^{8}$

Switchgrass (Panicum virgatum, L., Poaceae) is a promising biomass feedstock with a high yield and low input requirements. In addition, with the development of biotechnology, modified switchgrass is a dedicated energy crop to produce renewable chemicals and fuels. ${ }^{9}$ Switchgrass has the potential to serve as a critical resource to produce a range of materials, chemicals, and energy products due to its typical composition

Received: March 8, 2020

Accepted: August 11, 2020

Published: August 27, 2020 
Table 1. Main Compositions of Switchgrass from Varying Pretreatments ${ }^{a}$

\begin{tabular}{|c|c|c|c|c|c|}
\hline pretreatments & cellulose (glucose) & xylan & arabinan & AIL & ASL \\
\hline untreated switchgrass & $39.42 \pm 0.51$ & $17.27 \pm 0.04$ & $2.98 \pm 0.03$ & $19.82 \pm 0.62$ & $1.40 \pm 0.01$ \\
\hline $\mathrm{H}_{2} \mathrm{SO}_{4} 0.50 \%(\mathrm{v} / \mathrm{v}) 125{ }^{\circ} \mathrm{C} 30 \mathrm{~min}$ & $52.30 \pm 1.21$ & $6.67 \pm 0.14$ & $0.80 \pm 0.09$ & $24.84 \pm 0.66$ & $0.96 \pm 0.01$ \\
\hline $\mathrm{HCl} 0.50 \%(\mathrm{v} / \mathrm{v}) 125{ }^{\circ} \mathrm{C} 30 \mathrm{~min}$ & $53.72 \pm 0.77$ & $9.93 \pm 0.54$ & $1.00 \pm 0.12$ & $23.96 \pm 0.18$ & $1.46 \pm 0.24$ \\
\hline $\mathrm{H}_{3} \mathrm{PO}_{4} 1.00 \%(\mathrm{v} / \mathrm{v}) 130{ }^{\circ} \mathrm{C} 20 \mathrm{~min}$ & $49.20 \pm 0.35$ & $9.93 \pm 0.04$ & $0.82 \pm 0.04$ & $22.81 \pm 0.61$ & $1.22 \pm 0.01$ \\
\hline $\mathrm{CH}_{3} \mathrm{COOH} 0.50 \%(\mathrm{v} / \mathrm{v}) 115{ }^{\circ} \mathrm{C} 20 \mathrm{~min}$ & $36.75 \pm 1.52$ & $17.51 \pm 0.49$ & $3.63 \pm 0.08$ & $18.61 \pm 0.24$ & $1.66 \pm 0.01$ \\
\hline $\mathrm{HNO}_{3} 2.00 \%(\mathrm{v} / \mathrm{v}) 125{ }^{\circ} \mathrm{C} 30 \mathrm{~min}$ & $55.84 \pm 0.04$ & $4.38 \pm 0.01$ & $0.00 \pm 0.00$ & $11.56 \pm 0.25$ & $1.21 \pm 0.01$ \\
\hline $\mathrm{NaOH} 1.00 \%(\mathrm{w} / \mathrm{v}) 75{ }^{\circ} \mathrm{C} 60 \mathrm{~min}$ & $53.85 \pm 1.84$ & $18.96 \pm 0.04$ & $3.10 \pm 0.03$ & $10.03 \pm 0.09$ & $1.07 \pm 0.11$ \\
\hline $\mathrm{NH}_{4} \mathrm{OH} 8.00 \%(\mathrm{v} / \mathrm{v}) 75{ }^{\circ} \mathrm{C} 60 \mathrm{~min}$ & $42.85 \pm 0.32$ & $20.57 \pm 0.01$ & $3.26 \pm 0.02$ & $16.56 \pm 0.32$ & $1.45 \pm 0.19$ \\
\hline $\mathrm{Ca}(\mathrm{OH})_{2} 0.25 \%(\mathrm{v} / \mathrm{v}) 30{ }^{\circ} \mathrm{C} 120 \mathrm{~min}$ & $37.67 \pm 2.18$ & $18.21 \pm 0.32$ & $2.49 \pm 0.43$ & $19.14 \pm 1.12$ & $1.79 \pm 0.03$ \\
\hline AHP $8.00 \%(v / v) 130{ }^{\circ} \mathrm{C} 30 \mathrm{~min}$ & $50.80 \pm 0.27$ & $11.36 \pm 0.11$ & $1.61 \pm 0.02$ & $12.87 \pm 0.12$ & $1.41 \pm 0.02$ \\
\hline $\mathrm{C}_{2} \mathrm{H}_{5} \mathrm{OH} 80.00 \%(\mathrm{v} / \mathrm{v}) 150{ }^{\circ} \mathrm{C} 40 \mathrm{~min}$ & $58.56 \pm 0.33$ & $9.27 \pm 0.13$ & $0.73 \pm 0.01$ & $13.75 \pm 0.29$ & $1.41 \pm 0.13$ \\
\hline $\mathrm{FeCl}_{3} 0.05 \mathrm{M} 150{ }^{\circ} \mathrm{C} 30 \mathrm{~min}$ & $46.00 \pm 0.33$ & $10.02 \pm 0.43$ & $0.74 \pm 0.03$ & $26.27 \pm 0.25$ & $0.97 \pm 0.22$ \\
\hline hot water $115{ }^{\circ} \mathrm{C} 30 \mathrm{~min}$ & $41.77 \pm 0.08$ & $16.11 \pm 0.04$ & $3.08 \pm 0.01$ & $17.65 \pm 0.84$ & $0.97 \pm 0.01$ \\
\hline
\end{tabular}

${ }^{a}$ Note: All compositions are presented as $\mathrm{g} / 100 \mathrm{~g}$ of pretreated switchgrass besides the untreated raw switchgrass. AIL: acid-insoluble lignin. ASL: acid-soluble lignin.

of cellulose (32-45\% wt), hemicellulose (21-31\% wt), and lignin content $(12-28 \% \mathrm{wt}) .{ }^{10-16}$ Nowadays, this energy crop is being used for several industrial processes with biotechnology applications such as renewable energy, ${ }^{17}$ isoprenol production, ${ }^{18}$ cellulose, and protein extraction. ${ }^{19,20}$ However, there is still a lack of a comprehensive comparative study of different switchgrass pretreatment processes for further utilization of different purposes.

Going beyond of sugars from switchgrass, research studies also focus on papermaking and nanocellulose, but these technologies still require effective pretreatment to achieve desired switchgrass conversion. The ideal pretreatment to obtain fermentable sugars for production of biofuels and biochemicals is to eliminate lignin and preserve the maximum cellulose and hemicellulose, which can enhance their yields of fermentable sugars. In the production of pulp for papermaking, the choice of specific treatments is based on their delignification capacity, ${ }^{21}$ suggesting the need to maximize lignin removal with the pretreatment. Switchgrass has attracted significant attention as a renewable source for nanocrystalline cellulose extraction, which is a two-step process including pretreatment and acid hydrolysis. The pretreatment process is to ensure the removal of hemicelluloses and releasing the cellulose that can be used for further effective hydrolysis into the nanocellulose material. ${ }^{22,23}$

Some studies have focused on various pretreatment technologies for the conversion of switchgrass into soluble sugars. ${ }^{24}$ However, few research studies give a comprehensive insight into the comparison of composition details of chemical pretreatments on switchgrass. The present study tries to offer optimal and useful information on switchgrass chemical pretreatments on a laboratory scale, which will enable a better understanding of currently available pretreatments to improve switchgrass utilization. We characterized the physical and chemical changes of switchgrass when it was subjected to 12 pretreatments, including five dilute acid, four alkali, organosolv, ferric chloride, and hydrothermal pretreatments. Some pretreatments are applied for the first time. The practical details of the pretreatments presented in this study were used to choose the best strategies for enhancing the conversion process of switchgrass provide the guideline for better utilization of switchgrass.

\section{RESULTS AND DISCUSSION}

Composition of Switchgrass. The switchgrass raw material used in this study has a composition of $39.42 \pm$ $0.52 \% \mathrm{w} / \mathrm{w}$ cellulose, $20.25 \pm 0.01 \% \mathrm{w} / \mathrm{w}$ hemicellulose, and $21.22 \pm 0.62 \% \mathrm{w} / \mathrm{w}$ lignin. However, the concentrations of cellulose, hemicellulose, and lignin obtained in this study had a marginal variation from the values reported by others, ${ }^{25}$ which could be mainly attributed to species, cultivar differences, harvest maturity of the sample, and so on. The high cellulose and low lignin of switchgrass in this study indicate that this switchgrass is not only suitable as a feedstock for biofuel production but also an excellent resource for nanocellulose production and the pulp and paper industry.

Evaluation of the Influence of Various Parameters on the Dilute Acid Pretreatment Efficiency of Switchgrass. A completely randomized design with three replications was employed to compare the parameters of various mild dilute acid pretreatments of switchgrass, which was fundamentally ensured to retain cellulose and remove lignin. Further studies were conducted at the condition that the previous step no longer had a significant effect on residual cellulose and residual lignin. Table 1 shows the results of the five dilute acid pretreatments, and detailed experimental results are presented in the Supporting Information file.

Dilute sulfuric acid $\left(\mathrm{H}_{2} \mathrm{SO}_{4}\right)$ pretreatment has been studied extensively, which is efficient in the removal of hemicelluloses, rendering the cellulose more available. ${ }^{8} \mathrm{~A}$ concentration of $0.50 \% \mathrm{v} / \mathrm{v} \mathrm{H}_{2} \mathrm{SO}_{4}$ could yield $52.30 \%$ of residual cellulose and remove $62.62 \%$ of hemicelluloses $(7.57 \pm 0.23 \% \mathrm{w} / \mathrm{w})$ with the low temperature of $125{ }^{\circ} \mathrm{C}$ for $20 \mathrm{~min}$ (Figure 1). There was a slight improvement in the residual cellulose of treated samples with the increase of the concentration of $\mathrm{H}_{2} \mathrm{SO}_{4}$ to $2.00 \% \mathrm{v} / \mathrm{v}$ (Table S1 and Figure S1). However, there was no significant difference in the lignin content, suggesting that the optimal switchgrass pretreatment was using the $0.50 \% \mathrm{v} / \mathrm{v}$ $\mathrm{H}_{2} \mathrm{SO}_{4}$ under the temperature of $125{ }^{\circ} \mathrm{C}$ for $20 \mathrm{~min}$. Dilute $\mathrm{H}_{2} \mathrm{SO}_{4}$ pretreatment of switchgrass is generally performed at temperatures from 140 to $200{ }^{\circ} \mathrm{C}$ with an $\mathrm{H}_{2} \mathrm{SO}_{4}$ concentration of $0.50-2.00 \%$ and in a relatively short residence time $(<60 \mathrm{~min}) .^{26}$ In our process, the cellulose residue and lignin degradation could occur due to the low temperature and acid concentration.

Inhibitory products, including furfural, hydroxymethylfurfural (HMF), and other organic acids, are commonly generated 

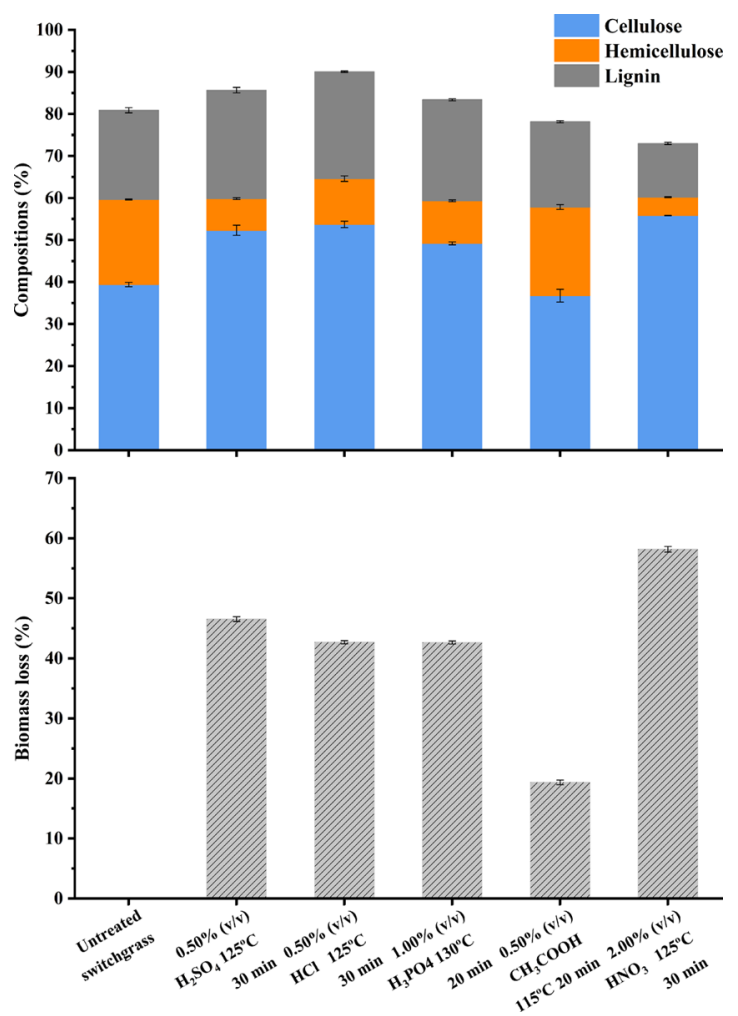

Figure 1. Chemical compositions and biomass loss of acid pretreated switchgrass.

during the hydrochloric acid $(\mathrm{HCl})$ pretreatment process at higher pretreatment temperatures, which are needed for $\mathrm{HCl}$ pretreatment of some lignocellulose biomass. However, $\mathrm{HCl}$ is frequently used in hydrolyzing lignocellulose because it is volatile and easy to recover. ${ }^{27}$ Little data is available on the $\mathrm{HCl}$ hydrolysis of switchgrass. In this article, we carried out a study to first evaluate the effect of different parameters on $\mathrm{HCl}$ pretreatment efficacy of switchgrass. Figure S2 shows the biomass loss, cellulose, hemicellulose, and lignin contents of switchgrass biomass samples after different dilute $\mathrm{HCl}$ pretreatments. Cellulose $(53.72 \%)$ in pretreated switchgrass was retained with the $0.50 \% \mathrm{v} / \mathrm{v} \mathrm{HCl}$ at $125^{\circ} \mathrm{C}$ for $20 \mathrm{~min}$ (Figure 1). It is observed that as the temperature or acid concentration increases, the hemicellulose decreases continuously, as shown in Figure S2 and Table S2, which would be promising in nanocrystalline cellulose extraction.

Phosphoric acid $\left(\mathrm{H}_{3} \mathrm{PO}_{4}\right)$ pretreatment of the lignocellulose biomass for biofuel production can increase the ethanol yields compared to other pretreatment strategies. ${ }^{28}$ Besides, residual $\mathrm{H}_{3} \mathrm{PO}_{4}$ can be used as a fertilizer for microbial growth. Thus, it has been used for the pretreatment of switchgrass and other biomasses. ${ }^{29}$ This study showed more details of $\mathrm{H}_{3} \mathrm{PO}_{4}$ pretreatment of switchgrass with four low temperatures (115, 120,125 , and $130{ }^{\circ} \mathrm{C}$ ). The result signified that the maximum cellulose preservation and lignin degradation for switchgrass pretreatment was obtained with $1.00 \% \mathrm{v} / \mathrm{v} \mathrm{H}_{3} \mathrm{PO}_{4}$ at $130{ }^{\circ} \mathrm{C}$ for $40 \mathrm{~min}$, with a high residual cellulose of 49.20 and $35.16 \%$ of lignin removal (Figure 1). In this stage, the three parameters of $\mathrm{H}_{3} \mathrm{PO}_{4}$ pretreatment had almost no effect on lignin degradation. However, $\mathrm{H}_{3} \mathrm{PO}_{4}$ concentration had a more significant impact on the hemicellulose solubilization than the other parameters (Figure S3).
Acetic acid $\left(\mathrm{CH}_{3} \mathrm{COOH}\right)$ attracts attention due to the autocatalysis occurring during the pretreatment of lignocelluloses. ${ }^{30}$ It is reported to facilitate the release of natural organic acids from the biomass and the organic acids act as a natural catalyst for the rupture of the lignin-carbohydrate complex. A number of studies have reported that organic acid pretreatment of the biomass needs high temperature and pressure. ${ }^{31}$ In this study, $\mathrm{CH}_{3} \mathrm{COOH}$ pretreatment under low temperatures would reduce energy consumption, and we used the same conditions as those for the other acids to investigate the impact of various acids on the pretreatment of switchgrass. The result showed that $\mathrm{CH}_{3} \mathrm{COOH}$ has little effect on the residual cellulose and lignin in treated samples (Figure 1). Similar results were reported for dilute $\mathrm{CH}_{3} \mathrm{COOH}$ pretreatment of switchgrass under the temperature of $150{ }^{\circ} \mathrm{C}$ for efficient biobutanol production by Wang et al. However, they reported that the cellulose content would increase when the temperature reached $190{ }^{\circ} \mathrm{C} . \mathrm{CH}_{3} \mathrm{COOH}$ used in the pretreatment of the lignocellulosic biomass plays an essential role in enhancing microbial production of high-value biofuels. ${ }^{17}$

This work evaluated the effect of subjecting switchgrass to nitric acid $\left(\mathrm{HNO}_{3}\right)$ pretreatment with different time periods, temperatures, and concentrations. After optimal $\mathrm{HNO}_{3}$ pretreatment, a relative increase in the cellulose content $(55.84 \pm 0.04 \% \mathrm{w} / \mathrm{w})$ and a significant decrease in hemicellulose $(4.38 \pm 0.01 \% \mathrm{w} / \mathrm{w})$ and lignin contents $(12.77 \pm 0.27 \% \mathrm{w} / \mathrm{w})$ were observed (Figure 1). Up to $40.00 \%$ of lignin was removed when the acid concentration was increased to $2.00 \%(\mathrm{v} / \mathrm{v})$ (Figure S5), which showed that the strength of $\mathrm{HNO}_{3}$ was a determinant factor for the $\mathrm{HNO}_{3}$ pretreatment of switchgrass. In addition, it was reported that the nitrate formed during the $\mathrm{HNO}_{3}$ pretreatment was a promising nitrogen source in the fermentation process. ${ }^{32}$

It is well known that acid pretreatment of lignocelluloses is a highly active process to obtain a suitable structure. Furthermore, dilute acid is a promising method to extract hemicellulose, ${ }^{7}$ which is also proved by this study. The most significant cellulose residue and delignification were observed on the $\mathrm{HNO}_{3}$ pretreatment of switchgrass, which can be used for nanocellulose or fermented sugar production. Besides, $\mathrm{H}_{3} \mathrm{PO}_{4}$ and $\mathrm{HNO}_{3}$ pretreatments of switchgrass show the significant potential for the production of low-cost biofuels and high-value biochemicals because the residual acid can be used as a fertilizer for microbial growth.

Comparison of the Alkaline Pretreatments of Switchgrass. In this study, the impact of the residence time ( $\mathrm{min})$, temperature $\left({ }^{\circ} \mathrm{C}\right)$, and concentration of the alkali $(\% \mathrm{v} / \mathrm{v}$ or $\%$ $\mathrm{w} / \mathrm{v}$ ) was examined for cellulose, hemicellulose, and lignin levels of the switchgrass biomass with the completely randomized design. The results of the four alkaline pretreatments are presented in Table 1 and in the Supporting Information file. They have been widely used in the pretreatment of biomass for production of paper and mixed sugars due to the solubilization of lignin in these methods.

In this work, the process designed not only maximizes cellulose release and lignin removal but also augments and identifies the optimal parameters. The experiment with $1.00 \%$ w/v sodium hydroxide $(\mathrm{NaOH})$ at $75{ }^{\circ} \mathrm{C}$ for 60 min results in $53.85 \%$ of residual cellulose and $11.10 \%$ of residual delignification in pretreated switchgrass (Figure 2). The high temperature was beneficial for lignin removal in the switchgrass pretreatment (Figure S6 and Table S6). Those results obtained 

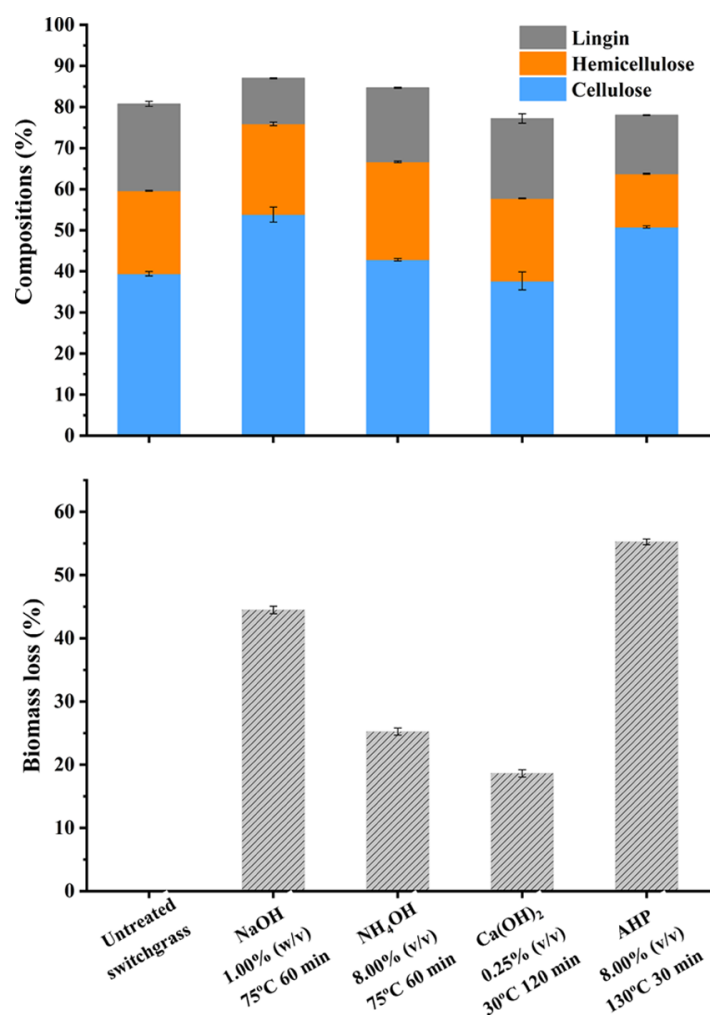

Figure 2. Chemical compositions and biomass loss of alkali pretreated switchgrass.

in the $\mathrm{NaOH}$ pretreatment study of switchgrass are consistent with Gao's findings. ${ }^{33}$

Chemical pretreatment with ammonia $\left(\mathrm{NH}_{4} \mathrm{OH}\right)$ can remove lignin with a minimal effect on hemicellulose degradation. ${ }^{34}$ Figure S7 and Table S7 show the details of the $\mathrm{NH}_{4} \mathrm{OH}$ pretreatment of switchgrass at varying treatment factors. The optimal condition for the $\mathrm{NH}_{4} \mathrm{OH}$ pretreatment is at a temperature of $75{ }^{\circ} \mathrm{C}$ for $60 \mathrm{~min}$ at a concentration of $8.00 \%\left(\mathrm{v} / \mathrm{v}\right.$ ) (Figure 2). $\mathrm{NH}_{4} \mathrm{OH}$ pretreatment does not cause hemicellulose degradation compared to other alkaline agents. A similar result was displayed by Cayetano et al. ${ }^{35}$ Additionally, previous studies have found that residual $\mathrm{NH}_{4} \mathrm{OH}$ concentrations would be toxic to bacteria, ${ }^{35,36}$ which would be an obstacle for bioconversion of lignocellulosic biomass.

Although lime $\left[\mathrm{Ca}(\mathrm{OH})_{2}\right]$ is not strong enough for pretreatment by itself, it is much cheaper and it is possible to recover calcium that can be used to improve the economic promise of alkaline pretreatment at an ambient temperature. ${ }^{37}$ Thus, $\mathrm{Ca}(\mathrm{OH})_{2}$ pretreatment of lignocellulosic biomass is drawing increasing attention. $\mathrm{Ca}(\mathrm{OH})_{2}$ pretreatment parameters of switchgrass were evaluated in this work, and the detailed results are presented in Figure S8. The poor performance of lime probably resulted from the poor solubility of lime in water and the lower pretreatment time used in this work. ${ }^{38}$ Future studies should be conducted with $\mathrm{Ca}(\mathrm{OH})_{2}$ and other reagent mixtures to improve the cost-effectiveness of switchgrass for biochemical processes and the pulp and paper manufacturing process.

The alkaline hydrogen peroxide (AHP) was regarded as an effective pretreatment for grass, corn stover, and other materials. ${ }^{39}$ We first explored several key parameters to test the potential of AHP for further improvement of switchgrass pretreatment. A cellulose yield of $50.80 \%$ is obtained using pretreatment of $8.00 \%(\mathrm{v} / \mathrm{v}) \mathrm{AHP}$ at $130{ }^{\circ} \mathrm{C}$ for $30 \mathrm{~min}$ (Figure 2). It could be seen that the successful pretreatment processes with a high cellulose yield were achieved in the pretreatment with a high AHP concentration. Other authors have reported the same behavior for different biomass pretreatments. $^{40}$

Although the retention of cellulose was lower in the alkaline pretreatments, most alkaline pretreatments can prevent hemicellulose loss and remove lignin at low temperatures. For the alkali pretreatments of switchgrass, $\mathrm{NaOH}$ was one of the best choices for optimizing lignin removal while minimizing carbohydrate loss, which could be successfully used in papermaking and biofuel production.

Study on Various Parameters of the Three Other Switchgrass Pretreatments. In the present study, the three other chemical pretreatments were also compared for the switchgrass utilization. Organosolv pretreatment has been proposed to modify the substrate chemically and physically. Figure S10 and Table S10 outline our strategies to improve the pretreatment of switchgrass using ethanol $\left(\mathrm{C}_{2} \mathrm{H}_{5} \mathrm{OH}\right)$ with a catalyst of $\mathrm{H}_{2} \mathrm{SO}_{4}$. The $\mathrm{C}_{2} \mathrm{H}_{5} \mathrm{OH}$ pretreatment removed $28.55 \%$ of lignins and $51.62 \%$ of hemicelluloses with $80 \%$ (v/v) $\mathrm{C}_{2} \mathrm{H}_{5} \mathrm{OH}$ at $150{ }^{\circ} \mathrm{C}$ for $40 \mathrm{~min}$ (Figure 3). Cateto et al.
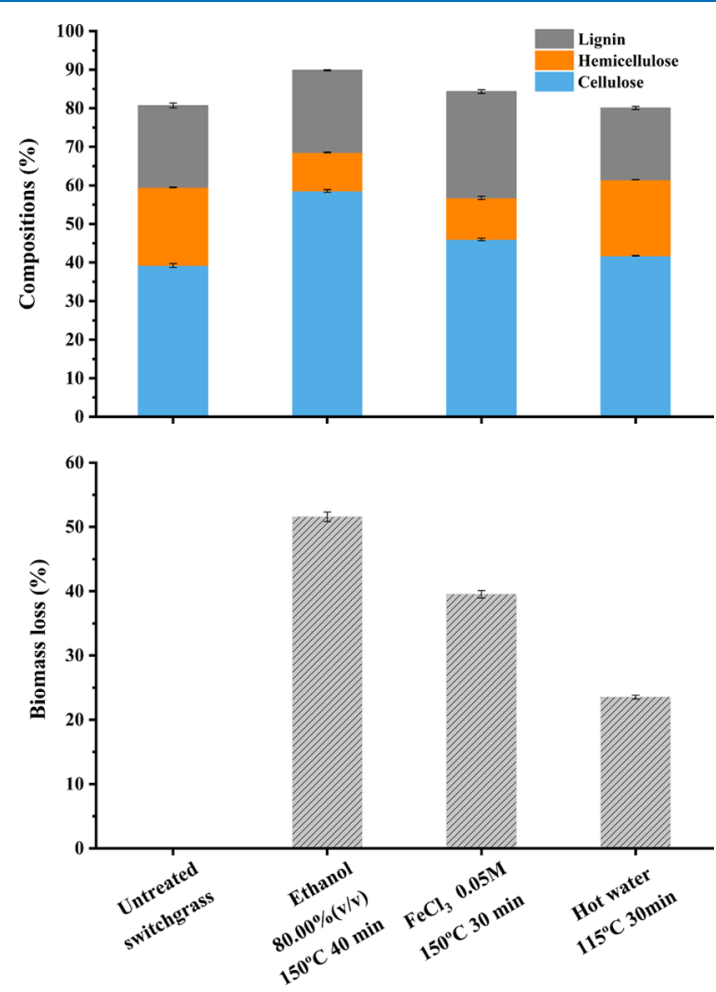

Figure 3. Chemical compositions of the three other pretreated switchgrass.

employed $75 \%$ of $\mathrm{C}_{2} \mathrm{H}_{5} \mathrm{OH}$ to treat Kanlow switchgrass and the pretreatment was performed at $180{ }^{\circ} \mathrm{C}$ for $1 \mathrm{~h}$ resulting in a $\sim 60.5 \%$ of lignin and $\sim 74.0 \%$ of hemicellulose loss. ${ }^{41}$ In this study, there was a slight increase in cellulose release and lignin removal with the increasing of the temperature and pretreatment duration. In addition, $\mathrm{C}_{2} \mathrm{H}_{5} \mathrm{OH}$ could be recovered by precipitation of pretreatment effluents, ${ }^{42}$ which makes the process much more sustainable and promising.

Although ferric chloride $\left(\mathrm{FeCl}_{3}\right)$ pretreatment hardly removes the lignin, it can efficiently remove the hemicellulose 

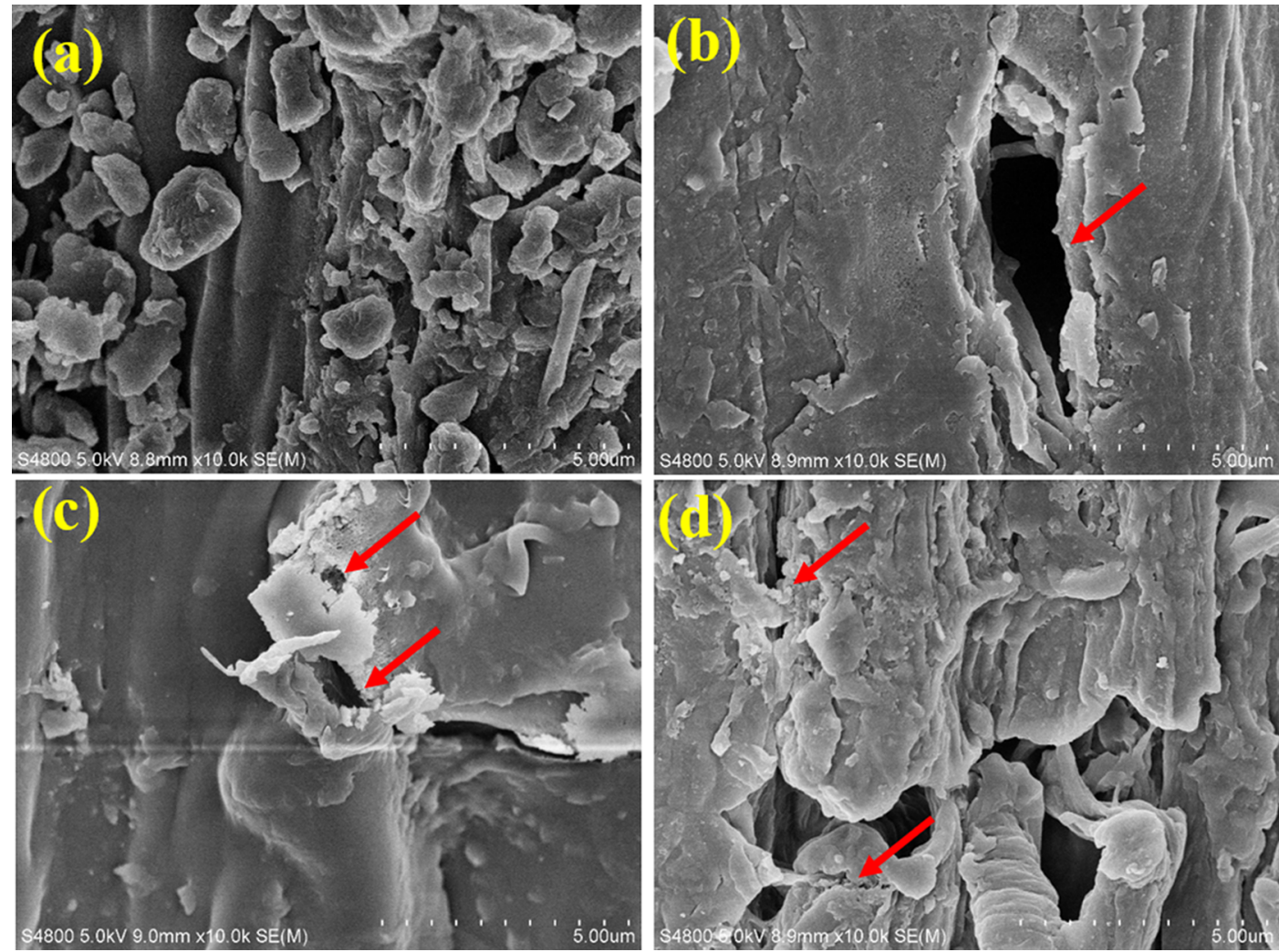

Figure 4. SEM images of untreated and pretreated switchgrass: (a) untreated switchgrass; (b) $\mathrm{HNO}_{3}$ pretreated switchgrass; (c) NaOH pretreated switchgrass; (d) $\mathrm{C}_{2} \mathrm{H}_{5} \mathrm{OH}$ pretreated switchgrass at $10000 \times$ magnification.

and break ether and ester linkages between lignin and carbohydrates. Moreover, it is recyclable. ${ }^{43}$ It is useful in the pretreatment of rice straw, bagasse, wood fiber, and Pennisetum alopecuroides. ${ }^{44}$ The effects of pretreatment durations, temperatures, and $\mathrm{FeCl}_{3}$ concentrations on the $\mathrm{FeCl}_{3}$ pretreatment of switchgrass were first studied, and the results are displayed in Figure 3. Samples pretreated with $0.05 \mathrm{M} \mathrm{FeCl}_{3}$ solution under $150{ }^{\circ} \mathrm{C}$ for 30 min exhibited maximum cellulose retention and hemicellulose removal.

Hot water pretreatment does not need catalysts and it is environment friendly. ${ }^{8}$ Moreover, due to its ability to separate nearly pure hemicellulose from the rest of the feedstock, hot water pretreatment has been widely used as part of overall processes in fractionating the components of the lignocellulosic biomass. In the present study, lower temperatures (105$135^{\circ} \mathrm{C}$ ) and short pretreatment durations $(15-60 \mathrm{~min})$ were used on the hot water pretreatment of switchgrass, and the results are displayed in Figure 3, Table S12, and Figure S12. The composition change of switchgrass was not apparent, which was consistent with the report of hot water pretreatment of brewers' spent grain. ${ }^{45}$

Structural Changes in the Three Optimal Pretreatments for Switchgrass. In this work, $\mathrm{HNO}_{3}, \mathrm{NaOH}$, and $\mathrm{C}_{2} \mathrm{H}_{5} \mathrm{OH}$ pretreatments were found to be the most effective switchgrass pretreatments. The effects on the surface morphology and crystalline structure of these three methods, at the investigated optimal conditions, were further studied. These results provided the most crucial evidence that the intact structures of raw switchgrass were disrupted and the cellulose, hemicellulose, and lignin were changed after pretreatments.

Scanning electron microscopy (SEM) images show the surface of untreated and treated switchgrass samples in Figure
4. The untreated sample had a compact, rough, and nonuniform surface, while the treated samples had some discernible changes that specifically manifested in the appearance of abrasion and a smooth surface, as well as some layering and scaling, which was possibly caused by lignin removal or hemicellulose degradation. ${ }^{46}$ The morphological structures of the pretreated samples were thus destroyed, making them advantageous for further utilization.

The crystalline structure could give the evidence of inherent components in the lignocellulosic biomass, and crystallinity in the biomass is mostly attributed to the cellulose. The crystallinity of switchgrass samples was assessed by X-ray diffraction in this work $^{47}$ (Figure 5a). There were no new peaks that appeared in pretreated samples, indicating that the three pretreatments did not bring changes in the cellulose crystalline allomorph. ${ }^{46}$ According to Reddy et al., ${ }^{48}$ diffraction peaks near $15-16,22.5$, and $35^{\circ}$ were originated from cellulose I. The results show that the peaks near $15-16,22.5^{\circ}$ became sharper in pretreated switchgrass, which implied that the crystallinity was increased. This may be correlated with the removal of lignin or hemicellulose, which is consistent with the results of the chemical composition analysis of pretreated samples.

The chemical structure of the lignocellulosic biomass is measured by FT-IR to identify the functional groups in the samples. Figure $5 b$ shows the FT-IR spectra of different switchgrass samples. The result analysis was conducted with the related public literature data. ${ }^{45,46,49}$ There was no significant difference between untreated switchgrass and pretreated switchgrass in the spectra, which implied that the three pretreatments did not affect the overall structure of switchgrass. The peaks at $1060 \mathrm{~cm}^{-1}$, which was characteristic 
(a)
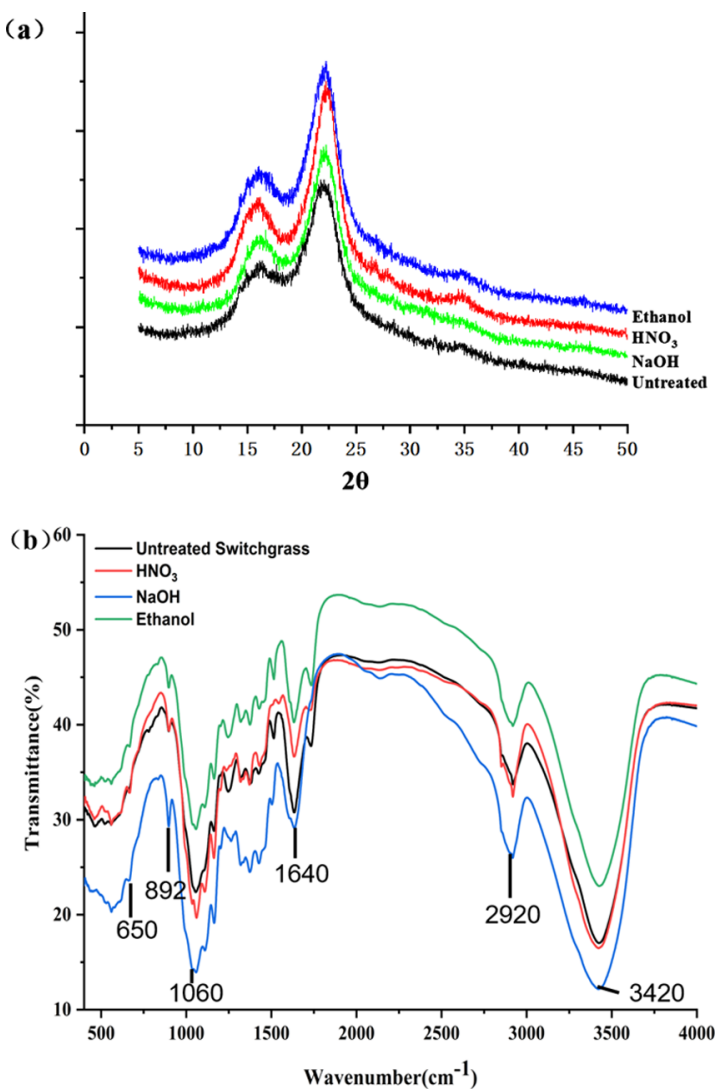

Figure 5. X-ray diffraction (XRD) pattern (a) and Fourier-transform infrared spectroscopy (FT-IR) spectra (b) of untreated and pretreated samples via $\mathrm{HNO}_{3}, \mathrm{NaOH}$, and $\mathrm{C}_{2} \mathrm{H}_{5} \mathrm{OH}$.

of cellulose, were observed after pretreatments. Peaks at wavelengths of 3420 and $2920 \mathrm{~cm}^{-1}$ can be used to evaluate the alteration of the cellulose structure. A decrease of these bands resulted from the breakdown of intermolecular hydrogen bonding in cellulose and hemicellulose, which might cause the changes in crystallinity in pretreated switchgrass.

\section{CONCLUSIONS}

Twelve different chemical pretreatment techniques were comparatively investigated to enhance switchgrass utilization and reduce energy consumption. SEM, XRD, and FT-IR analyses were further conducted to confirm the structural changes in three optimal pretreated samples. Besides, $\mathrm{HCl}$, $\mathrm{AHP}$, and $\mathrm{FeCl}_{3}$ were employed first to investigate the effect on pretreatment of the switchgrass biomass. In conclusion, $\mathrm{NaOH}$-pretreated switchgrass had a high residual cellulose and low residual lignin under the low temperature while the $\mathrm{HNO}_{3}$ and $\mathrm{C}_{2} \mathrm{H}_{5} \mathrm{OH}$ pretreatments also had the potential to be suitable pretreatment methods for different utilization purposes of switchgrass. Furthermore, $\mathrm{HNO}_{3}$ and $\mathrm{H}_{3} \mathrm{PO}_{4}$ were highly recommended in pretreatment of switchgrass for biofuels.

\section{EXPERIMENTAL SECTION}

Sample Processing. Switchgrass was donated by the Key Laboratory of Biofuels, Shandong Provincial Key Laboratory of Energy Genetics, Qingdao Institute of Bioenergy and Bioprocess Technology, Chinese Academy of Sciences. Switchgrass was dried at $42{ }^{\circ} \mathrm{C}$ for $72 \mathrm{~h}$ and after that the dry samples were ground and sieved using a $425 \mu \mathrm{m}$ opening sieve. It was then stored at a temperature of $20-25^{\circ} \mathrm{C}$ in a dry place for further experiments.

Pretreatment. Acid Hydrolysis. The acid hydrolysis of switchgrass samples was carried out with $\mathrm{H}_{2} \mathrm{SO}_{4}, \mathrm{HCl}, \mathrm{H}_{3} \mathrm{PO}_{4}$, $\mathrm{CH}_{3} \mathrm{COOH}$, and $\mathrm{HNO}_{3}^{8,45,52}$ to investigate the effect of various acids on switchgrass. First, the ground samples $(2.50 \mathrm{~g})$ were dispersed into $50 \mathrm{~mL}$ of $0.50 \%(\mathrm{v} / \mathrm{v})$ acid solutions and then exposed to steam in a pressure vessel at $120{ }^{\circ} \mathrm{C}$ for distinct periods $(20,30,40$, and $50 \mathrm{~min})$, respectively. After the pretreatment, the sample was collected by filtration, washed thoroughly with three volumes of distilled water (500 $\mathrm{mL}$ ) and dried at $42{ }^{\circ} \mathrm{C}$ for the biomass loss analysis and chemical composition analysis. Further, the samples $(2.50 \mathrm{~g})$ were mixed with $50 \mathrm{~mL}$ of $0.50 \%(\mathrm{v} / \mathrm{v})$ acid solutions and then exposed to steam in a pressure vessel at four different temperatures $\left(115,120,125\right.$, and $\left.130{ }^{\circ} \mathrm{C}\right)$ for the best pretreatment period from chemical composition analysis of previous experiments. After the pretreatment, the solids were thoroughly washed with deionized water to neutrality, collected by filtration and dried at $42{ }^{\circ} \mathrm{C}$ for the biomass loss analysis and chemical composition analysis. Finally, the biomass $(2.50 \mathrm{~g})$ was added into $50 \mathrm{~mL}$ of varying concentrations of the acid $(0.25,0.50,1.00$, and $2.00 \% \mathrm{v} / \mathrm{v})$ and exposed to steam in a pressure vessel using the optimal pretreatment period and temperature from the chemical composition analysis of previous experiments. After the pretreatment, the resulting sample was collected by filtration and washed thoroughly with three volumes of distilled water $(500 \mathrm{~mL})$ and dried at $42{ }^{\circ} \mathrm{C}$ for the biomass loss analysis and chemical composition analysis. Each experiment was repeated in triplicate under the same conditions to ensure the reproducibility of the results, which were expressed as mean values \pm standard deviation (SD).

Alkaline Hydrolysis. The effects of $\mathrm{NaOH}$ concentrations $(0.50,1.00,1.50$, and $2.00 \% \mathrm{w} / \mathrm{v})$, temperatures $(65,75,85$, and $\left.95{ }^{\circ} \mathrm{C}\right)$, and time periods $(30,60,90$, and $120 \mathrm{~min})$ on the yield of cellulose, hemicellulose. and lignin were studied with the single factor experiment. The experimental processes were the same as acid hydrolysis, whose details are illustrated in Table S6. The effects of $\mathrm{NH}_{4} \mathrm{OH}$ concentrations $(6.00,8.00$, 10.00 , and $12.00 \% \mathrm{w} / \mathrm{v})$, temperatures $\left(65,75,85\right.$, and $\left.95{ }^{\circ} \mathrm{C}\right)$, time periods $(30,60,90$, and $120 \mathrm{~min})$, and the impacts of $\mathrm{Ca}(\mathrm{OH})_{2}$ concentrations $(0.25,0.50,1.00$, and $2.00 \% \mathrm{w} / \mathrm{v})$, temperatures $\left(25,30,35\right.$, and $\left.40{ }^{\circ} \mathrm{C}\right)$, time periods $(2,4,6$, and $8 \mathrm{~h}$ ), as well as, the effects of AHP concentrations (0.50, $1.00,6.00,7.00$ and $8.00 \% \mathrm{v} / \mathrm{v})$, temperatures $(65,75,85$, and $\left.95{ }^{\circ} \mathrm{C}\right)$, and time periods $(30,60,90$, and $120 \mathrm{~min})$ on the yield of cellulose, hemicellulose, and lignin were studied in the same way. The $\mathrm{H}_{2} \mathrm{O}_{2}$ solution is adjusted to $\mathrm{pH} 11.0$ with 6 $\mathrm{mol} / \mathrm{L} \mathrm{NaOH}$ to prepare AHP. Each experiment was repeated in triplicate under the same conditions to ensure the reproducibility of the results, expressed as mean values \pm standard deviation (SD).

$\mathrm{C}_{2} \mathrm{H}_{5} \mathrm{OH}$ Treatment. Organosolv pretreatment was performed as described by Ravindran et al. ${ }^{45}$ with an optimization process. Briefly, the samples $(2.50 \mathrm{~g})$ were dispersed into 50 $\mathrm{mL}$ of $60.00 \%(\mathrm{v} / \mathrm{v}) \mathrm{C}_{2} \mathrm{H}_{5} \mathrm{OH}$ solution, which was made with $1 \% \mathrm{H}_{2} \mathrm{SO}_{4}(\mathrm{v} / \mathrm{v})$ as a catalyst, in a $500 \mathrm{~mL}$ pressure bottle and then heated at $150{ }^{\circ} \mathrm{C}$ for distinct periods $(20,30,40$, and 50 min), respectively. After the pretreatment, the solids were thoroughly washed with deionized water to neutrality, collected by filtration and dried at $42{ }^{\circ} \mathrm{C}$ for the biomass loss analysis and chemical composition analysis. Further, the 
samples $(2.50 \mathrm{~g})$ were mixed with $60.00 \%(\mathrm{v} / \mathrm{v}) \mathrm{C}_{2} \mathrm{H}_{5} \mathrm{OH}$ solution $(50 \mathrm{~mL})$ and then heated at four different temperatures $\left(140,150,160\right.$, and $\left.170{ }^{\circ} \mathrm{C}\right)$ for the best pretreatment period from the chemical composition analysis of previous experiments. After the pretreatment, the solids were thoroughly washed with deionized water to neutrality, collected by filtration and dried at $42{ }^{\circ} \mathrm{C}$ for the biomass loss analysis and chemical composition analysis. Finally, the biomass $(2.50 \mathrm{~g})$ was added into $50 \mathrm{~mL}$ varying concentrations of $\mathrm{C}_{2} \mathrm{H}_{5} \mathrm{OH}(60.00,70.00,80.00$, and $90.00 \% \mathrm{v} / \mathrm{v})$ and then heated with the optimal pretreatment period and temperature from the chemical composition analysis of previous experiments. After the pretreatment, the solids were thoroughly washed with deionized water to neutrality, collected by filtration and dried at $42{ }^{\circ} \mathrm{C}$ for the biomass loss analysis and stored in a cool and dry place until further chemical composition analysis. Each experiment was repeated in triplicate under the same conditions to ensure the reproducibility of the results, expressed as mean values \pm standard deviation (SD).

$\mathrm{FeCl}_{3}$ Pretreatment. $\mathrm{FeCl}_{3}$ pretreatment of switchgrass was implemented according to the procedure described by Chen et al. ${ }^{43}$ Raw biomass $(2.50 \mathrm{~g})$ was treated with $50 \mathrm{~mL}$ of $\mathrm{FeCl}_{3}$ solution and the effects of $\mathrm{FeCl}_{3}$ concentrations (0.01, 0.05, 0.10 , and $0.2 \mathrm{M})$, temperatures $\left(140,150,160\right.$, and $\left.170{ }^{\circ} \mathrm{C}\right)$, and time periods $(20,30,40$, and $50 \mathrm{~min})$ were investigated. The experiment processes were the same as those in $\mathrm{C}_{2} \mathrm{H}_{5} \mathrm{OH}$ treatment, whose details can be found in Table S11. Each experiment was repeated in triplicate under the same conditions to ensure the reproducibility of the results, expressed as mean values \pm standard deviation (SD).

Hot Water Treatment. Hot water pretreatment of switchgrass was performed as described by Ravindran et al. ${ }^{45}$ with a slight modification. Switchgrass $(2.50 \mathrm{~g})$ was moistened with $50 \mathrm{~mL}$ of water. Moreover, the effects of pretreated temperatures $\left(105,115,125\right.$, and $\left.135{ }^{\circ} \mathrm{C}\right)$ and time periods $(15,30,45$, and $60 \mathrm{~min})$ in a stainless-steel autoclave were studied. The experiment processes were the same as those in $\mathrm{C}_{2} \mathrm{H}_{5} \mathrm{OH}$ treatment and the details can be found in Table S12. Each experiment was repeated in triplicate under the same conditions to ensure the reproducibility of the results, expressed as mean values \pm standard deviation (SD).

Pretreated Switchgrass Characterization. SEM, X-ray diffraction, and FT-IR were used to observe the changes in the surface, crystallinity, and chemical structure of the four optimal pretreatments of the switchgrass biomass, respectively, using the methods mentioned by Wang et al. ${ }^{46}$ The surface structures of untreated and pretreated switchgrass samples were analyzed with a SEM (Hitachi S-4800, Hitachi, Ltd.). XRD analysis was conducted using a Bruker D8 Advance XRD system (Germany). FT-IR analysis was carried out using a Nicolet 6700 FT-IR spectrometer (Thermo Fisher). Untreated and pretreated samples mixed with spectroscopic grade potassium bromide $(1: 20)$ were obtained within the spectral range of 400-4000 $\mathrm{cm}^{-1}$.

Chemical Composition Measurement. Chemical compositions of the native and pretreated switchgrass samples were performed according to the National Renewable Energy Laboratory (NREL) protocol with a slight modification. ${ }^{50,51}$ Briefly, $300 \pm 10 \mathrm{mg}$ of the sample was mixed into $3.00 \pm 0.01$ $\mathrm{mL}$ of $72 \%(\mathrm{w} / \mathrm{w})$ sulfuric acid and shaken at $30{ }^{\circ} \mathrm{C}$ for 60 min. Then, adding $84.00 \pm 0.04 \mathrm{~mL}$ of deionized water, the mixture was incubated at $121{ }^{\circ} \mathrm{C}$ for $60 \mathrm{~min}$. When the mixture was cooled to room temperature, the residue was removed by filtration to determine the acid-insoluble lignin (AIL) content. High-performance liquid chromatography (HPLC) determined the supernatant with a refractive index detector (RID). The Bio-Rad Aminex HPX-87H column $(7.8 \mathrm{~mm} \times$ $300 \mathrm{~mm}, 9 \mu \mathrm{m}$ ) was used for monosaccharide determination at $60{ }^{\circ} \mathrm{C}$. A final amount of $5 \mathrm{mmol} / \mathrm{L} \mathrm{H}_{2} \mathrm{SO}_{4}$ was used as the mobile phase at a flow rate of $0.6 \mathrm{~mL} / \mathrm{min}$. Besides, the acidsoluble lignin (ASL) content in the liquid was detected using a UV-visible spectrophotometer.

\section{ASSOCIATED CONTENT}

\section{Supporting Information}

The Supporting Information is available free of charge at https://pubs.acs.org/doi/10.1021/acsomega.0c01047.

Tables and figures of the results of 12 pretreatment optimization processes (PDF)

\section{AUTHOR INFORMATION}

\section{Corresponding Author}

Haibo Zhang - Key Laboratory of Biobased Materials, Qingdao Institute of Bioenergy and Bioprocess Technology, Chinese Academy of Sciences, Qingdao, Shandong 266101, China; SinoDanish College, University of Chinese Academy of Sciences, Beijing 100049, China; Phone: +86 1396978 0438; Email: zhanghb@qibebt.ac.cn

\section{Authors}

Fan Wang - Key Laboratory of Biobased Materials, Qingdao Institute of Bioenergy and Bioprocess Technology, Chinese Academy of Sciences, Qingdao, Shandong 266101, China; SinoDanish College, University of Chinese Academy of Sciences, Beijing 100049, China; 이이이.org/0000-0003-3301-8189

Dongxiang Shi - Key Laboratory of Biobased Materials, Qingdao Institute of Bioenergy and Bioprocess Technology, Chinese Academy of Sciences, Qingdao, Shandong 266101, China; Lanzhou University of Technology, Lanzhou, Gansu 730050, China

Ju Han - Key Laboratory of Biobased Materials, Qingdao Institute of Bioenergy and Bioprocess Technology, Chinese Academy of Sciences, Qingdao, Shandong 266101, China; SinoDanish College, University of Chinese Academy of Sciences, Beijing 100049, China

Ge Zhang - Key Laboratory of Biobased Materials, Qingdao Institute of Bioenergy and Bioprocess Technology, Chinese Academy of Sciences, Qingdao, Shandong 266101, China; SinoDanish College, University of Chinese Academy of Sciences, Beijing 100049, China

Xinglin Jiang - The Novo Nordisk Foundation Center for Biosustainability, Technical University of Denmark, Kongens Lyngby 2800, Denmark

Mingjun Yang - Lanzhou University of Technology, Lanzhou, Gansu 730050, China

Zhenying Wu - Key Laboratory of Biobased Materials, Qingdao Institute of Bioenergy and Bioprocess Technology, Chinese Academy of Sciences, Qingdao, Shandong 266101, China

Chunxiang Fu - Key Laboratory of Biobased Materials, Qingdao Institute of Bioenergy and Bioprocess Technology, Chinese Academy of Sciences, Qingdao, Shandong 266101, China 
Zhihao Li - Key Laboratory of Biobased Materials, Qingdao Institute of Bioenergy and Bioprocess Technology, Chinese Academy of Sciences, Qingdao, Shandong 266101, China

Mo Xian - Key Laboratory of Biobased Materials, Qingdao Institute of Bioenergy and Bioprocess Technology, Chinese Academy of Sciences, Qingdao, Shandong 266101, China; SinoDanish College, University of Chinese Academy of Sciences, Beijing 100049, China

Complete contact information is available at: https://pubs.acs.org/10.1021/acsomega.0c01047

\section{Notes}

The authors declare no competing financial interest.

\section{ACKNOWLEDGMENTS}

This work was supported by Young Taishan Scholars (grant number TSQN201909159), the Youth Innovation Promotion Association, CAS (grant number 2017252), and the Dalian National Laboratory for Clean Energy (DNL), CAS (grant number QIBEBT I201934).

\section{REFERENCES}

(1) Adel, A. M.; El-Gendy, A. A.; Diab, M. A.; Abou-Zeid, R. E.; ElZawawy, W. K.; Dufresne, A. Microfibrillated cellulose from agricultural residues. Part I: Papermaking application. Ind. Crops Prod. 2016, 93, 161-174.

(2) Balch, M. L.; Holwerda, E. K.; Davis, M. F.; Sykes, R. W.; Happs, R. M.; Kumar, R.; Wyman, C. E.; Lynd, L. R. Lignocellulose fermentation and residual solids characterization for senescent switchgrass fermentation by Clostridium thermocellum in the presence and absence of continuous in situ ball-milling. Energy Environ. Sci. 2017, 10, 1252-1261.

(3) Himmel, M. E.; Shi-You, D.; David, K. J.; William, S. A.; Mark, R. N.; John, W. B.; Foust, T. D. Biomass recalcitrance: Engineering plants and enzymes for biofuels production. Science 2007, 315, 804807.

(4) Kumar, B.; Bhardwaj, N.; Agrawal, K.; Chaturvedi, V.; Verma, P. Current perspective on pretreatment technologies using lignocellulosic biomass: An emerging biorefinery concept. Fuel Process. Technol. 2020, 199, No. 106244.

(5) Djioleu, A.; Carrier, D. J. Effects of dilute acid pretreatment parameters on sugar production during biochemical conversion of switchgrass using a full factorial design. ACS Sustainable Chem. Eng. 2016, 4, 4124-4130.

(6) Cantero, D.; Jara, R.; Navarrete, A.; Pelaz, L.; Queiroz, J.; Rodriguez-Rojo, S.; Cocero, M. J. Pretreatment Processes of Biomass for Biorefineries: Current Status and Prospects. Annu. Rev. Chem. Biomol. Eng. 2019, 10, 289-310.

(7) Woiciechowski, A. L.; Dalmas Neto, C. J.; Souza Vandenberghe, L. P.; Carvalho Neto, D. P.; Novak Sydney, A. C.; Letti, L. A. J.; Karp, S. G.; Zevallos Torres, L. A.; Soccol, C. R. Lignocellulosic biomass: Acid and alkaline pretreatments and their effects on biomass recalcitrance - Conventional processing and recent advances. Bioresour. Technol. 2020, 304, No. 122848.

(8) Agbor, V. B.; Cicek, N.; Sparling, R.; Berlin, A.; Levin, D. B. Biomass pretreatment: fundamentals toward application. Biotechnol. Adv. 2011, 29, 675-685.

(9) Fu, C.; Mielenz, J. R.; Xiao, X.; Ge, Y.; Hamilton, C. Y.; Rodriguez, M., Jr.; Chen, F.; Foston, M.; Ragauskas, A.; Bouton, J.; Dixon, R. A.; Wang, Z. Y. Genetic manipulation of lignin reduces recalcitrance and improves ethanol production from switchgrass. Proc. Natl. Acad. Sci. U.S.A. 2011, 108, 3803-3808.

(10) Pasangulapati, V.; Ramachandriya, K. D.; Kumar, A.; Wilkins, M. R.; Jones, C. L.; Huhnke, R. L. Effects of cellulose, hemicellulose and lignin on thermochemical conversion characteristics of the selected biomass. Bioresour. Technol. 2012, 114, 663-669.
(11) Falls, M.; Sierra-Ramirez, R.; Holtzapple, M. T. Oxidative lime pretreatment of Dacotah switchgrass. Appl. Biochem. Biotechnol. 2011, $165,243-259$.

(12) Isci, A.; Himmelsbach, J. N.; Pometto, A. L., 3rd; Raman, D. R.; Anex, R. P. Aqueous ammonia soaking of switchgrass followed by simultaneous saccharification and fermentation. Appl. Biochem. Biotechnol. 2008, 144, 69-77.

(13) Reshamwala, S.; Shawky, B. T.; Dale, B. E. Ethanol production from enzymatic hydrolysates of AFEX-treated coastal bermudagrass and switchgrass. Appl. Biochem. Biotechnol. 1995, 51/52, 43-55.

(14) Kumar, S.; Kothari, U.; Kong, L.; Lee, Y. Y.; Gupta, R. B. Hydrothermal pretreatment of switchgrass and corn stover for production of ethanol and carbon microspheres. Biomass Bioenergy 2011, 35, 956-968.

(15) Falls, M.; Shi, J.; Ebrik, M. A.; Redmond, T.; Yang, B.; Wyman, C. E.; Garlock, R.; Balan, V.; Dale, B. E.; Pallapolu, V. R.; Lee, Y. Y.; Kim, Y.; Mosier, N. S.; Ladisch, M. R.; Hames, B.; Thomas, S.; Donohoe, B. S.; Vinzant, T. B.; Elander, R. T.; Warner, R. E.; SierraRamirez, R.; Holtzapple, M. T. Investigation of enzyme formulation on pretreated switchgrass. Bioresour. Technol. 2011, 102, 1107211079.

(16) Hu, Z.; Sykes, R.; Davis, M. F.; Charles Brummer, E.; Ragauskas, A. J. Chemical profiles of switchgrass. Bioresour. Technol. 2010, 101, 3253-3257.

(17) Wang, P.; Chen, Y. M.; Wang, Y.; Lee, Y. Y.; Zong, W.; Taylor, S.; McDonald, T.; Wang, Y. Towards comprehensive lignocellulosic biomass utilization for bioenergy production: Efficient biobutanol production from acetic acid pretreated switchgrass with Clostridium saccharoperbutylacetonicum N1-4. Appl. Energy 2019, 236, 551-559.

(18) Wang, S.; Zhao, W.; Lee, T. S.; Singer, S. W.; Simmons, B. A.; Singh, S.; Yuan, Q.; Cheng, G. Dimethyl sulfoxide assisted ionic liquid pretreatment of switchgrass for isoprenol production. ACS Sustainable Chem. Eng. 2018, 6, 4354-4361.

(19) Pingali, S. V.; Urban, V. S.; Heller, W. T.; McGaughey, J.; O’Neill, H. M.; Foston, M.; Myles, D. A.; Ragauskas, A. J.; Evans, B. R. SANS study of cellulose extracted from switchgrass. Acta Crystallogr., Sect. D: Biol. Crystallogr. 2010, 66, 1189-1193.

(20) Bals, B.; Teachworth, L.; Dale, B.; Balan, V. Extraction of proteins from switchgrass using aqueous ammonia within an integrated biorefinery. Appl. Biochem. Biotechnol. 2007, 143, 187-198.

(21) Karp, E. M.; Resch, M. G.; Donohoe, B. S.; Ciesielski, P. N.; O’Brien, M. H.; Nill, J. E.; Mittal, A.; Biddy, M. J.; Beckham, G. T. Alkaline pretreatment of switchgrass. ACS Sustainable Chem. Eng. 2015, 3, 1479-1491.

(22) Lee, H. V.; Hamid, S. B. A.; Zain, S. K. Conversion of lignocellulosic biomass to nanocellulose: Structure and chemical process. Sci. World J. 2014, 2014, No. 631013.

(23) Mishra, S.; Kharkar, P. S.; Pethe, A. M. Biomass and waste materials as potential sources of nanocrystalline cellulose: Comparative review of preparation methods (2016 - Till date). Carbohydr. Polym. 2019, 207, 418-427.

(24) Garlock, R. J.; Balan, V.; Dale, B. E.; Pallapolu, V. R.; Lee, Y. Y.; Kim, Y.; Mosier, N. S.; Ladisch, M. R.; Holtzapple, M. T.; Falls, M.; Sierra-Ramirez, R.; Shi, J.; Ebrik, M. A.; Redmond, T.; Yang, B.; Wyman, C. E.; Donohoe, B. S.; Vinzant, T. B.; Elander, R. T.; Hames, B.; Thomas, S.; Warner, R. E. Comparative material balances around pretreatment technologies for the conversion of switchgrass to soluble sugars. Bioresour. Technol. 2011, 102, 11063-11071.

(25) Başar, İ.A.; Kökdemir Ünşar, E.; Ünyay, H.; Perendeci, N. A. Ethanol, methane, or both? Enzyme dose impact on ethanol and methane production from untreated energy crop switchgrass varieties. Renewable Energy 2020, 149, 287-297.

(26) Nlewem, K. C.; Thrash, M. E., Jr. Comparison of different pretreatment methods based on residual lignin effect on the enzymatic hydrolysis of switchgrass. Bioresour. Technol. 2010, 101, 5426-5430.

(27) Bensah, E. C.; Mensah, M. Chemical pretreatment methods for the production of cellulosic ethanol: Technologies and innovations. Int. J. Chem. Eng. 2013, 2013, 1-21. 
(28) Geddes, C. C.; Mullinnix, M. T.; Nieves, I. U.; Peterson, J. J.; Hoffman, R. W.; York, S. W.; Yomano, L. P.; Miller, E. N.; Shanmugam, K. T.; Ingram, L. O. Simplified process for ethanol production from sugarcane bagasse using hydrolysate-resistant Escherichia coli strain MM160. Bioresour. Technol. 2011, 102, 27022711.

(29) Wu, W.; Rondon, V.; Weeks, K.; Pullammanappallil, P.; Ingram, L. O.; Shanmugam, K. T. Phosphoric acid based pretreatment of switchgrass and fermentation of entire slurry to ethanol using a simplified process. Bioresour. Technol. 2018, 251, 171-180.

(30) Duff, S. J. B.; Murray, W. D. Bioconversion of forest products industry waste cellulosics to fuel ethanol: A review. Bioresour. Technol. 1996, 55, 1-33.

(31) Peng, J.; Abomohra, A. E. F.; Elsayed, M.; Zhang, X.; Fan, Q.; $\mathrm{Ai}, \mathrm{P}$. Compositional changes of rice straw fibers after pretreatment with diluted acetic acid: Towards enhanced biomethane production. J. Cleaner Prod. 2019, 230, 775-782.

(32) Kim, I.; Lee, B.; Park, J. Y.; Choi, S. A.; Han, J. I. Effect of nitric acid on pretreatment and fermentation for enhancing ethanol production of rice straw. Carbohydr. Polym. 2014, 99, 563-567.

(33) Gao, K.; Boiano, S.; Marzocchella, A.; Rehmann, L. Cellulosic butanol production from alkali-pretreated switchgrass (Panicum virgatum) and phragmites (Phragmites australis). Bioresour. Technol. 2014, 174, 176-181.

(34) Kim, T. H.; Lee, Y. Y. Fractionation of corn stover by hot-water and aqueous ammonia treatment. Bioresour. Technol. 2006, 97, 224232.

(35) Cayetano, R. D. A.; Oliwit, A. T.; Kumar, G.; Kim, J. S.; Kim, S.-H. Optimization of soaking in aqueous ammonia pretreatment for anaerobic digestion of African maize bran. Fuel 2019, 253, 552-560.

(36) Chen, Y.; Cheng, J. J.; Creamer, K. S. Inhibition of anaerobic digestion process: A review. Bioresour. Technol. 2008, 99, 4044-4064.

(37) Kaar, W. E.; Holtzapple, M. T. Using lime pretreatment to facilitate the enzymic hydrolysis of corn stover. Biomass Bioenergy 2000, 18, 189-199.

(38) Xu, J.; Cheng, J. J.; Sharma-Shivappa, R. R.; Burns, J. C. Lime pretreatment of switchgrass at mild temperatures for ethanol production. Bioresour. Technol. 2010, 101, 2900-2903.

(39) Banerjee, G.; Car, S.; Scott-Craig, J. S.; Hodge, D. B.; Walton, J. D. Alkaline peroxide pretreatment of corn stover: Effects of biomass, peroxide, and enzyme loading and composition on yields of glucose and xylose. Biotechnol. Biofuels 2011, 4, 16.

(40) Rabelo, S. C.; Andrade, R. R.; Maciel Filho, R.; Costa, A. C. Alkaline hydrogen peroxide pretreatment, enzymatic hydrolysis and fermentation of sugarcane bagasse to ethanol. Fuel 2014, 136, 349357.

(41) Cateto, C.; Hu, G.; Ragauskas, A. Enzymatic hydrolysis of organosolv Kanlow switchgrass and its impact on cellulose crystallinity and degree of polymerization. Energy Environ. Sci. 2011, 4, 1516.

(42) Hu, G.; Cateto, C.; Pu, Y.; Samuel, R.; Ragauskas, A. J. Structural characterization of switchgrass lignin after ethanol organosolv pretreatment. Energy Fuels 2012, 26, 740-745.

(43) Chen, L. H.; Chen, R.; Fu, S. $\mathrm{FeCl}_{3}$ pretreatment of three lignocellulosic biomass for ethanol production. ACS Sustainable Chem. Eng. 2015, 3, 1794-1800.

(44) Tang, S. Y.; Xu, C. M.; Vu, L. T. K.; Liu, S. C.; Ye, P.; Li, L. C.; Wu, Y. X.; Chen, M. Y.; Xiao, Y.; Wu, Y.; Wang, Y. N.; Yan, Q.; Cheng, X. Y. Enhanced enzymatic hydrolysis of pennisetum alopecuroides by dilute acid, alkaline and ferric chloride pretreatments. Molecules 2019, 24, 1715.

(45) Ravindran, R.; Jaiswal, S.; Abu-Ghannam, N.; Jaiswal, A. K. A comparative analysis of pretreatment strategies on the properties and hydrolysis of brewers' spent grain. Bioresour. Technol. 2018, 248, 272279.

(46) Wang, M.; Zhou, D.; Wang, Y.; Wei, S.; Yang, W.; Kuang, M.; Ma, L.; Fang, D.; Xu, S.; Du, S. K. Bioethanol production from cotton stalk: A comparative study of various pretreatments. Fuel 2016, 184, 527-532.
(47) Segal, L.; Creely, J. J.; Martin, A. E.; Conrad, C. M. An empirical method for estimating the degree of crystallinity of native cellulose using the X-ray diffractometer. Text. Res. J. 1959, 29, 786794.

(48) Reddy, N.; Yang, Y. Properties and potential applications of natural cellulose fibers from the bark of cotton stalks. Bioresour. Technol. 2009, 100, 3563-3569.

(49) Thi, S.; Lee, K. M. Comparison of deep eutectic solvents (DES) on pretreatment of oil palm empty fruit bunch (OPEFB): Cellulose digestibility, structural and morphology changes. Bioresour. Technol. 2019, 282, 525-529.

(50) Liu, L.; Yang, J. S.; Yang, Y.; Luo, L. J.; Wang, R. N.; Zhang, Y.; Yuan, H. L. Consolidated bioprocessing performance of bacterial consortium EMSD5 on hemicellulose for isopropanol production. Bioresour. Technol. 2019, 292, No. 121965.

(51) Chuetor, S.; Champreda, V.; Laosiripojana, N. Evaluation of combined semi-humid chemo-mechanical pretreatment of lignocellulosic biomass in energy efficiency and waste generation. Bioresour. Technol. 2019, 292, No. 121966.

(52) Viliame, S.; Shogo, K.; Yuko, S.; Tomohito, K.; Yoshioka, T. Effects of acetic acid pretreatment and pyrolysis temperatures on product recovery from fijian sugarcane bagasse. Waste Biomass Valorization 2019, 1, 1-11. 